\title{
Probabilistic Composition for Fast Group Decisions
}

\author{
Annibal Parracho Sant'Anna \\ Helio Darwich Nogueira \\ Lucia Mathias Rabelo \\ Universidade Federal Fluminense (UFF), Niterói, RJ, Brazil
}

\begin{abstract}
A methodology to deal with choice by a group of decision makers is here developed. Its first step consists on obtaining individual evaluations of the available options. These evaluations are seen as estimates of location parameters of random variables and each vector of individual evaluations of the whole set of options is transformed into a vector of probabilities of being ranked as the best choice by that individual decision maker. The next step is the probabilistic composition of such individual vectors of probabilities into a unique vector of aggregate preferences. To do that different composition procedures may be applied. The comparison of the results of distinct composition strategies is employed to detect outliers in the individual evaluations and, fnally, to filter the best options. After the initial evaluations are obtained, the whole process may be automatically developed. This makes the methodology particularly useful when fast decisions are needed. Its applicability is here illustrated by a case of daily revision of a stocks portfolio.
\end{abstract}

Keywords: Multicriteria decision analysis, Probabilistic composition, Fast decision, Stocks portfolio.

\section{Introduction}

There are circumstances where a fast decision must be taken and group participation, by bringing different information on the options under evaluation or on relevant features of them, may considerably improve the decision process. Typical decisions with this pair of features are those named operational decisions. A military troop facing a sudden enemy attack or a health team receiving a victim of a recent injury are concrete examples of such situations. We consider here a third example, of purchasing or selling stocks to fit a portfolio to a volatile market reality.

Operational decisions may be improved by the developments in information technology that accelerate the precise formulation of the questions to be solved and provide means to collect instantaneous evaluation from many evaluators, at any physical distance from each other. The part of this problem that we address here is that of automatically composing distinct evaluations of the available options into global rankings of such options, then deciding on correcting any individual evaluation and finally deriving a coherent classification.

After the problem is precisely formulated, the evaluation process starts by offering the evaluators a small list of possible values easy to deal with, such as levels 
in a Likert (1932) scale, to be assigned to the options. Mistakes in filling the forms or uncertainty in determining the preferred answers may occur. By these reasons, the values prompted by any evaluator in the evaluation sheet may always be taken not as precise numbers but as observations of random variables. The probabilistic composition of the preferences starts by considering such values as estimates of location parameters of the respective probability distributions.

The statistical model is completed by assumptions on independence of errors and on the form of the distributions. Each vector of initial individual evaluations is then replaced by a vector of probabilities of each option being that with the largest preference in a possible replication of the same data generation process.

The composition procedure must be sensitive to inconsistencies and contradictions between the individual evaluations in such a way as to hint on additional checks to be performed before entering the classification stage. The probabilistic approach allows for the application of different points of view to combine the individual evaluations into global scores. The contradictions between the results of application of such distinct points of view may inform on the possible presence of inconsistent answers and to select evaluators generating discrepant evaluations to be more carefully checked in an eventual second round of individual evaluations.

The composition points of view here considered belong to the set proposed in Sant'Anna (2002). They are obtained by taking extreme positions on two distinct axes: pessimistic $\times$ optimistic and conservative $\times$ progressive. A progressive point of view takes as reference to be followed the best performances, while a conservative point of view takes as reference the worst performances to be avoided. After choosing the progressive point of view, the pessimistic point of view takes as global score the probability of obtaining the best rank from all the evaluations while the optimistic point of view takes as the global score the probability of reaching such extreme position according to, not necessarily all, but at least one of the evaluators. Conversely if the conservative approach is taken.

The idea behind Sant'Anna (2002) approach is the same of Data Envelopment Analysis (Charnes et al., 1978) of evaluating by the distance to a frontier determined by the set of available observations. The advantage of the probabilistic approach is that, by measuring the distances in terms of probabilities, not only the frontier of best performances and its inverse may be taken as reference, but also different rules may be taken for the composition, like those derived from points of view above referred as optimistic and pessimistic.

The different approaches here considered lead to four different vectors of scores, whose contradictions will unfold the presence of discrepant individual evaluations possibly present in the data set. The comparison between the results of the optimistic and the pessimistic point of view at the two extremes, conservative and progressive, allows for detecting disparate values on particular evaluations. For instance, coherent evaluations along the evaluators will result in better classifications by the pessimistic points of view while good evaluations according to only a part of the evaluators will result in comparatively better evaluations according to the optimistic points of view. 
After revising the evaluations to correct for identifiable sources of deviations, the final decision is taken. If the different points of view lead to the choice of the same option, the evaluation process is concluded. Otherwise, unless there are reasons to prefer a particular point of view, a tie is established between the options contradictorily ranked in the final vectors of ranks. So, to equally rank options with contradictory preferences according to different composition approaches, the final result is given in terms of ordered classes. In particular, this allows for identifying sets of best and of worst options in classes of equally desirable and equally undesirable options.

The derivation of the individual probabilities from the observations is similar to the transformation of crisp numbers into membership intervals in Fuzzy Sets theory (Zadeh, 1965). A triangular distribution with mode at the observed value and sufficiently distant extremes may be assumed. The alternative taken in the case here studied consists on assuming a normal distribution with mean at the observed value and a constant standard deviation estimated with basis on the dispersion observed in the observed sample. Uniform or trapezoidal distributions might be chosen too. This makes possible taking as starting point any kind of evaluation, like, for instance, measures of different attributes considered the most important by each decision maker.

The next section discusses the fast operational decision problem. This is followed by a review of probabilistic composition. Then the application of the methodology to an enlightening example is presented.

\section{The Operation Decision Problem}

Multicriteria Decision-Making (MCDM) problems arise in situations such as that of a group of decision-makers facing a problem of choosing the best among several possible options. The main steps of MCDM can be stated as establishing evaluation criteria that relate attributes to goals, developing alternative systems for attaining the goals, evaluating options in terms of the selected criteria, applying a normative multicriteria analysis method and producing a final classification.

Classical MCDM problems usually deal with judgments presented as crisp numerical values. On the other hand, information about the options is often imprecise or the decision makers can only give approximate, incomplete or not well-defined information. The ability to deal with imprecise subjective information is particularly important when dealing with operational decisions, where the speed in reaching a decision and start action is impending. The key issue is then to choose fast composition rules for determination of aggregate rankings.

Many different composition rules have been proposed to deal with operational decisions, each of them with its own desirable properties. The first efforts to deal in a systematic way with group fast decisions may be traced to Bronner (1982) and Eisenhardt (1989). Along the next years, continuations of these efforts are found in Cohen et al. (1996), Lehner et al. (1997) and Fisher et al. (2003), for instance. More recent research still point to the need to develop new forms of treatment to the problem (Laxmisan et al., 2007; Louvieris et al., 2010; Larson, 2010; Walk, 2011).

Each evaluator may have their own idiosyncratic preferences over the options and the purpose of the composition rule is to reach a compromise that fairly counterbalances the different reasons that make each opinion important. Each evaluator 
taking into account the different attributes in a different way, it may become hard to decide if some evaluations are more relevant than others. Which composition rule is optimal depends on the kind of problem and the set of attributes that such kind of problem may permit observing.

The members of the group may disagree about the ranking of a set of options because they disagree about which options are more likely to lead them to their common goal. In such a context, we may believe that there is a correct ranking, in the sense that some options really are more likely than others to lead to that common goal. But, given the lack of enough time to discuss the problem to make clear what is the correct reasoning, the individual evaluations become estimates of the right values deviated by the presence of noise. Then, based on these noisy estimates, what can be produced is an aggregate ranking that is as close as possible to the correct ranking.

Operational decision problems are characterized by the importance of speed in the decision process. Communications and data-transfer capabilities have improved dramatically in the last years the ability to precisely formulate problems as they are rising and bring together answers from independent evaluators. A fast information flow may permit to set and remake a group evaluation process online. Even in less urgent contexts, the speed in setting and combining information may be useful to allow for centering attention in validating the components of the data set that are shown to be important by the results initially attained.

The presence in the decision team of people affected by the results of the decision or more directly involved on some less accessible aspect of the problem may be as important as that of specialists in critical aspects of the decision. This is the case of the patients to be submitted to a treatment, the parents of a small child in a nursery or the relatives of old people and mental patients assisted by doctors and social agents. Such participants may counterbalance the lack of technical information on the subject with a deeper knowledge of important features of the real case. If they are really unable to a proper contribution, we may expect that they will throw less distinct answers in the information sheets. We may take this as a general rule and include in the decision model a way to take precision and correction into account.

Another reason that justifies a probabilistic point of view is that the evaluation frequently involves some qualitative attributes. To deal with problems such as imprecision and subjectivity in measurements, Fuzzy Sets theory (Zadeh, 1965) provides a basis simple to operate and easy to understand. It applies general assumptions to treat individual measurements as approximations to real values.

Employing fuzzy evaluations may help in solving some difficulties frequently encountered in decision-making when it makes sense to think of each evaluation as a noisy estimate of the correct rank. Replacing crisp numbers by membership intervals, the fuzzy approach mainly aims to reduce the effects of imprecision in human judgment and preferences while searching for the optimal decision. On the other hand, the application of fuzzy logic (Zadeh, 1978) to combine the evaluations may yield some loss of information in multiple criteria composition as it applies principles of sufficiency and necessity to combine the information, what leads to disregard the contribution of those evaluators that present median evaluations. 
Another natural way to combine probabilistic evaluations into a global score is, considering such evaluations as conditional on the choice of the respective criteria, computing a weighted average, with weights given by a marginal distribution of probability among the criteria. In this approach the difficulty stays in obtaining such probabilities of choice of the criteria.

To deal with this difficulty a kind of Bayesian exit has been developed by Charnetski and Soland (1978) and Lahdelma et al. (1998). It consists on replacing the constant weights by probability distributions. In some cases it is possible to assume simple distributions for the weights and the problem is transferred to the determination of the space of their possible values. Final scores for each option are derived from the volume of the fraction of this space where such option is chosen as the best. But, even in the simplest cases, the meaning of these final scores may become difficult to grasp. The probabilistic forms of composition described in the next section allow for generating the final scores as joint probabilities easy to interpret. Under the assumption of independence between the stochastic disturbances affecting the evaluations set by the individual evaluators, the observed values are combined in a multiplicative way, inducing properties similar to those of the simple geometric mean. Besides, it allows for taking into account the numerical distances, alleviating the burden of searching for disregarded differences.

\section{Probabilistic Composition}

We deal here with the following framework. A set of $n$ options, $\mathrm{O}_{1}, \ldots, \mathrm{O}_{n}$, from which one is to be chosen and a set of $m$ decision makers or criteria applicators, $\mathrm{C}_{1}, \ldots, \mathrm{C}_{m}$. The $\mathrm{j}$-th decision maker presents for the $i$-th option an evaluation $\mathrm{E}_{i j}$. From $\mathrm{E}_{j}=\left(\mathrm{E}_{l j}, \ldots, \mathrm{E}_{n j}\right)$, the vector of evaluations according to the $j$-th evaluator, for each $j$, is derived a vector of probabilistic preferences $\mathrm{P}_{j}=\left(\mathrm{P}_{l j}, \ldots, \mathrm{P}_{n j}\right)$. The preference $\mathrm{P}_{i j}$ is given by the probability of the $i$-th entry being the largest in a hypothetical vector of observations $\mathrm{E}_{\mathrm{j}}^{*}=\left(\mathrm{E}_{1 j}{ }^{*}, \ldots, \mathrm{E}_{n j}{ }^{*}\right)$ of random variables with independent distributions with modes on the $n$ initial evaluations $\mathrm{E}_{1 j}, \ldots, \mathrm{E}_{n j}$.

To compute these probabilities $\mathrm{P}\left[\mathrm{E}_{i j}{ }^{*} \geq \mathrm{E}_{k j}{ }^{*}\right.$ for all $k$ from 1 to $\left.n\right]$, further assumptions must be made on the distribution of the $\mathrm{E}_{i j}{ }^{*}$. Independent triangular distributions with extremes $\mathrm{E}_{0 j}=0$ and $\mathrm{E}_{L j}=10$ provide a way to deal with the case of the initial evaluations given in a Likert scale of 9 points. For the general case, is here chosen a normal distribution, traditionally adopted in the case of measurement errors due to subjective factors or, more generally, to any combination of a large number of independent small factors.

Then, the distributions of the $\mathrm{E}_{i j}{ }^{*}$ are here independent normal with mean at the observed value $\mathrm{E}_{i j}$. To completely determine their distribution it remains to model the variances. To deal with the usual lack of information on dispersion of random errors an exit consists in assuming a constant variance for the evaluations according to each criterion and employing the observed values to estimate such constant variance. That means, the variance of $\mathrm{E}_{k j}{ }^{*}$ is assumed to be the same for all $k$ and is estimated by the variance observed in the sample $\left(\mathrm{E}_{1 j}, \ldots, \mathrm{E} n j\right)$. As the variation along the means is not necessarily a good estimate for the variation around each mean, if information on the coefficient of variation is available it may be employed to correct this estimate. 
In the normal case, to overpass the constraint of independence it is enough to determine correlation coefficients. Such correlations are nevertheless difficult to determine and their influence on the final results may be of difficult interpretation. Independence between evaluations of different options is usually accepted if combined with constant dispersion along the options. To obtain independence between errors affecting evaluations of a same option by different evaluators an effort is needed in the step of data collection, which is preferable to take, in the context of fast decision, to make easier the interpretation of the final results.

Finally, a preferences composition rule is needed to combine the individual evaluations into a global evaluation. Formally, a preferences composition rule is a mapping $\mathrm{F}$ that derives from the matrix $\mathrm{E}_{n X m}$ of individual evaluations $\mathrm{E}_{i j}$ for the set $\mathrm{A}$ of $n$ options by the set $\mathrm{C}$ of $m$ criteria or evaluators, a unique vector $\left(\mathrm{F}(\mathrm{E})_{1}, \ldots, F(E)_{n}\right)$ of preferences for the $n$ options. An option $i$ for which $\mathrm{F}(\mathrm{E})_{i} \geq \mathrm{F}(\mathrm{E})_{k}$ for all $k$ from 1 to $n$ is a most preferred option for the preferences composition rule $\mathrm{F}$ and the matrix of individual preferences $\mathrm{E}$.

Among the most valued properties of composition rules in the long research tradition on voting rules initialized with the seemingly surprising results of Arrow (1951) are those of monotonicity, neutrality and satisfaction of the Pareto condition. A preferences composition rule $\mathrm{F}$ is monotonic if, for every pair of matrices of preferences $\mathrm{D}$ and $\mathrm{E}$ on $\mathrm{A}$ and every pair of options $i_{1}$ and $i_{2}$ of $\mathrm{A}$ satisfying $\mathrm{D}_{i l j} \geq \mathrm{D}_{i 2 j}$ if and only if $\mathrm{E}_{i l j} \geq \mathrm{E}_{2 j}, \mathrm{~F}(\mathrm{D})_{i 1} \geq \mathrm{F}(\mathrm{D})_{i 2}$ implies $\mathrm{F}(\mathrm{E})_{i 1} \geq \mathrm{F}(\mathrm{E})_{i 2}$. A preferences composition rule is neutral if, for any permutation $\mathrm{P}$ of $\mathrm{A}$ and any matrix $\mathrm{E}$ of individual preferences about the options in $\mathrm{A}, \mathrm{F}(\mathrm{P}(\mathrm{E}))=\mathrm{P}(\mathrm{F}(\mathrm{E}))$. A preferences composition rule $\mathrm{F}$ satisfies the Pareto condition if, for every matrix of individual preferences $\mathrm{E}$ and every pair of options $i_{1}$ and $i_{2}, \mathrm{E}_{i 1 j} \geq \mathrm{E}_{i 2 j}$, for every evaluator $j$, implies $\mathrm{F}(\mathrm{E})_{i 1} \geq \mathrm{F}(\mathrm{E})_{i 2}$. From the definition of probabilistic composition presented in the following, it will easily follow that the probabilistic composition according to any of the considered points view, is monotonic, neutral and satisfy the Pareto condition.

A property that the probabilistic composition fails to satisfy is that of independence of third options. When combining evaluations of a group of evaluators, it is to be expected that the information about other options modify the preference between any two options. This happens because the information on other options changes the perceptions that the individuals have of the importance of attributes of the options in the context determined by the range of values observed for the set of all options being evaluated. This naturally changes the distances between evaluations of the two options initially referred, what may change their combined scores in such a way as producing rank reversals. The composition by combining probabilities of reaching extreme positions reduces the importance of options with values away from the frontiers to be reached and turns clearer the role of those options close to such frontiers of making explicit the criterion applied by each evaluator.

The key computation in the evaluation of the probabilistic scores is the determination of the probabilities of each option being preferred to all the others. The probability of considering a particular option as the best one is a natural measure of the decision maker preference for that option. 
The probabilities of an option being the first according to a given evaluator may be computed by integrating with respect to the joint density the probability of such option presenting a value better than that of each other option. To compute this probability it is convenient to divide the integration interval into sub-intervals bounded by the values in the sample.

After computing the probabilities of being the preferred option of each evaluator, it is easy to combine them into a unique measure of global preference. The strategy here applied to combine the probabilistic preferences is in terms of joint preference. This avoids the need of assigning weights to the evaluators.

As anticipated above, different joint probabilities will be obtained, depending on the point of view adopted. For instance, instead of combining the probabilities of being the best, we may combine the probabilities of not being the worst. The first approach is that named progressive and the second that named conservative. Besides, different points of view are characterized in terms of choice between an extremely optimistic and an extremely pessimistic position. The optimistic extreme consists of considering enough the preference by no more than one evaluator. All evaluators are taken into account, but the joint probability of preference by an option is that of at least one of them preferring such option. The composition employs the connective 'or'. On the opposite end, the pessimistic preference goes for options that satisfy every evaluator. The connective is 'and'. The joint probability computed is that of maximizing simultaneously the preferences of all the evaluators. The terms optimistic and pessimistic are related to the idea of confiding that the most favourable or the less favourable evaluator, respectively, will prevail.

These two points of view are combined with the choice of the frontier of best values or of worst values as the progressive or the conservative point of view is taken. If the results of the application of these points of view disagree, one of them must prevail. Practical reasons should be found, for instance, to judge more important to avoid bad evaluations of a few evaluators or to count on good evaluations of a few of them.

Even if we have, from the beginning, preference for one of these points of view, discordance between them may hint on errors to be corrected in the evaluation process. In fact, even if there is a preferable composition point of view, the confirmation of final ranks derived from the preferred composition approach by other approaches increases the confidence of the decision makers. The information on which options would be chosen from a different point of view will anyhow help by calling attention to strong and weak features of the options chosen.

And if preference among the approaches is not to be established the process will be concluded with divergences transformed into ties.

\section{Fast Portfolio Correction}

The problem here considered is that of the choice of the best move to change a portfolio in the stock market. A portfolio of shares of a set of 61 titles is to be object of daily exchange. The titles initially in the portfolio are those composing an Index of Enterprises with Sustainability Values recently created in BM\&FBOVESPA, the Sao Paulo Stock and Futures Exchange. 
To allow for replications of the computations, evaluation according to different criteria is here employed, instead of subjective experts evaluation. The shares are compared in terms of three classical attributes of fundamental stocks analysis: price/earnings, market presence and variation ratio. These three ratios gauge the three most important features of a stock: profitability, liquidity and volatility. They are here combined to provide global approximate evaluations of the opportunity of buying or selling the shares that the investor owns at a given moment.

The price/earnings ratio is the ratio between the current price of the share and the firm average earnings per share outstanding along the year. The market presence of a share is the ratio between the total value of the transactions dealt in the market in the last day and the volume of trade of such share. The variation ratio is the measure of the dispersion of the prices of the share in the last day trade, determined by dividing the maximum by the minimum observed trade value.

The choice of these variables for the present model is only due to their obviousness. The exercise here developed intends only to show the method in its feature of fast deriving a choice from any kind of variables. It takes these indicators as chosen and does not intend to bring evidence in favour or against their use. Other indicators may show more informative on trends to be explored. It remains admissible, for instance, the use of the inverse of these variables, based on the argument that, in the short run, observing classical explanatory variables contradicted, may hint on some yet unknown reason to buy.

For each share, the three observed values are transformed into probabilities of being the best and of being the worst. Each probability of being the best is given by the probability of presenting the minimum value of the indicator in a sample of 61 random variables each one drawn from a normal distribution with mean at the value of the indicator in the stock evaluated, as described in the preceding section. Analogously, the probability of being the worst is the probability of presenting the maximum value in such a sample.

The normal distribution was chosen due to the elaborate feature of the indicators employed, which subjects the measurements to the compensatory influence of small random disturbances. The standard deviations in the measurements of an indicator are estimated by the standard deviation in the sample of observations of such indicator, reflecting the view that the variability in the disturbances are constant for each indicator and increase with the variability in the values observed for that indicator.

The probabilistic composition is employed to choose a small number of different shares to be bought or sold. Optimistic and pessimistic compositions are computed for the probabilities of being the best and of being the worst. If these compositions lead to different choices, larger classes of shares are formed, by the rule of not leaving out of the selection any option that outranks at least one that is selected by the optimistic or by the pessimistic composition.

If the resulting classes are large classes, this should be due to extreme probabilities of maximization or minimization for some options by some criteria and very low probabilities by other criteria. This in fact happens to the values in Table 1, derived from data of 2011, January 13, of BM\&FBOVESPA. Table 1 presents the probabilities of each stock maximizing and minimizing the score according to each 
Table 1. Probabilities of maximizing and minimizing separate criteria.

\begin{tabular}{|c|c|c|c|c|c|c|}
\hline \multirow[t]{2}{*}{ Title } & \multicolumn{3}{|c|}{ Probability of maximization } & \multicolumn{3}{|c|}{ Probability of minimization } \\
\hline & $\mathrm{P} / \mathrm{E}$ & Inverted \% & MAX/MIN & $\mathrm{P} / \mathrm{E}$ & Inverted \% & MAX/MIN \\
\hline ALLL3 & $9,51 \mathrm{E}-06$ & $3,67 \mathrm{E}-05$ & $4,22 \mathrm{E}-04$ & $8,31 \mathrm{E}-04$ & $1,48 \mathrm{E}-02$ & $2,36 \mathrm{E}-04$ \\
\hline AMBV4 & $3,20 \mathrm{E}-07$ & $1,03 \mathrm{E}-05$ & $2,98 \mathrm{E}-04$ & $1,23 \mathrm{E}-02$ & $3,20 \mathrm{E}-02$ & $3,64 \mathrm{E}-04$ \\
\hline BBAS3 & $9,00 \mathrm{E}-08$ & $8,64 \mathrm{E}-06$ & $3,02 \mathrm{E}-06$ & 2,59E-02 & $3,52 \mathrm{E}-02$ & 1,94E-02 \\
\hline BBDC4 & $1,50 \mathrm{E}-07$ & $8,64 \mathrm{E}-06$ & $3,31 \mathrm{E}-06$ & 1,97E-02 & $3,52 \mathrm{E}-02$ & $1,83 \mathrm{E}-02$ \\
\hline BISA3 & $1,40 \mathrm{E}-07$ & $6,22 \mathrm{E}-04$ & $1,77 \mathrm{E}-05$ & 2,07E-02 & $1,43 \mathrm{E}-03$ & $5,69 \mathrm{E}-03$ \\
\hline BRFS3 & $9,20 \mathrm{E}-06$ & 1,91E-05 & $6,07 \mathrm{E}-06$ & $8,59 \mathrm{E}-04$ & 2,24E-02 & 1,24E-02 \\
\hline BRTO4 & $9,00 \mathrm{E}-08$ & $1,96 \mathrm{E}-04$ & 2,69E-04 & $2,56 \mathrm{E}-02$ & $4,21 \mathrm{E}-03$ & $4,12 \mathrm{E}-04$ \\
\hline BTOW3 & $1,11 \mathrm{E}-03$ & 7,74E-04 & $4,32 \mathrm{E}-05$ & $1,15 \mathrm{E}-06$ & $1,14 \mathrm{E}-03$ & $2,70 \mathrm{E}-03$ \\
\hline BVMF3 & $3,50 \mathrm{E}-07$ & 7,69E-06 & $3,68 \mathrm{E}-06$ & $1,16 \mathrm{E}-02$ & $3,74 \mathrm{E}-02$ & $1,71 \mathrm{E}-02$ \\
\hline $\mathrm{CCRO} 3$ & $7,90 \mathrm{E}-07$ & $1,54 \mathrm{E}-04$ & $6,62 \mathrm{E}-06$ & $6,74 \mathrm{E}-03$ & $5,16 \mathrm{E}-03$ & $1,17 \mathrm{E}-02$ \\
\hline CESP6 & $9,99 \mathrm{E}-01$ & 9,69E-06 & $1,14 \mathrm{E}-05$ & $1,00 \mathrm{E}-08$ & $3,30 \mathrm{E}-02$ & 7,91E-03 \\
\hline CIEL3 & $1,20 \mathrm{E}-07$ & $1,62 \mathrm{E}-05$ & $1,49 \mathrm{E}-05$ & $2,28 \mathrm{E}-02$ & $2,47 \mathrm{E}-02$ & $6,49 \mathrm{E}-03$ \\
\hline CMIG4 & $1,40 \mathrm{E}-07$ & $1,62 \mathrm{E}-05$ & $6,30 \mathrm{E}-07$ & $2,03 \mathrm{E}-02$ & $2,47 \mathrm{E}-02$ & $4,62 \mathrm{E}-02$ \\
\hline CPFE3 & $1,60 \mathrm{E}-07$ & 2,27E-04 & $2,38 \mathrm{E}-06$ & $1,92 \mathrm{E}-02$ & $3,72 \mathrm{E}-03$ & $2,24 \mathrm{E}-02$ \\
\hline CPLE6 & $1,80 \mathrm{E}-07$ & $2,38 \mathrm{E}-05$ & $3,73 \mathrm{E}-06$ & 1,79E-02 & $1,95 \mathrm{E}-02$ & $1,70 \mathrm{E}-02$ \\
\hline CRUZ3 & $2,90 \mathrm{E}-07$ & $5,61 \mathrm{E}-05$ & $4,06 \mathrm{E}-05$ & $1,32 \mathrm{E}-02$ & $1,11 \mathrm{E}-02$ & $2,85 \mathrm{E}-03$ \\
\hline CSAN3 & $1,80 \mathrm{E}-07$ & $6,22 \mathrm{E}-05$ & $2,48 \mathrm{E}-05$ & $1,77 \mathrm{E}-02$ & $1,03 \mathrm{E}-02$ & 4,33E-03 \\
\hline CSNA3 & $1,90 \mathrm{E}-07$ & $1,53 \mathrm{E}-05$ & $7,21 \mathrm{E}-06$ & 1,71E-02 & $2,55 \mathrm{E}-02$ & $1,10 \mathrm{E}-02$ \\
\hline CYRE3 & $1,40 \mathrm{E}-07$ & 2,13E-05 & $5,39 \mathrm{E}-05$ & $2,05 \mathrm{E}-02$ & 2,09E-02 & $2,21 \mathrm{E}-03$ \\
\hline DTEX3 & $2,20 \mathrm{E}-07$ & $1,78 \mathrm{E}-04$ & $4,03 \mathrm{E}-06$ & $1,54 \mathrm{E}-02$ & 4,57E-03 & $1,62 \mathrm{E}-02$ \\
\hline ELET3 & $9,00 \mathrm{E}-08$ & 2,81E-05 & $1,76 \mathrm{E}-04$ & $2,70 \mathrm{E}-02$ & $1,76 \mathrm{E}-02$ & $6,67 \mathrm{E}-04$ \\
\hline ELET6 & $1,00 \mathrm{E}-07$ & 1,09E-04 & $2,33 \mathrm{E}-04$ & $2,52 \mathrm{E}-02$ & $6,80 \mathrm{E}-03$ & $4,85 \mathrm{E}-04$ \\
\hline ELPL4 & $7,00 \mathrm{E}-08$ & $1,04 \mathrm{E}-04$ & $5,71 \mathrm{E}-06$ & $3,04 \mathrm{E}-02$ & 7,07E-03 & $1,29 \mathrm{E}-02$ \\
\hline EMBR3 & $2,50 \mathrm{E}-07$ & $1,71 \mathrm{E}-05$ & $9,85 \mathrm{E}-01$ & $1,46 \mathrm{E}-02$ & 2,39E-02 & $1,00 \mathrm{E}-08$ \\
\hline FIBR3 & $2,05 \mathrm{E}-06$ & $8,91 \mathrm{E}-05$ & $4,39 \mathrm{E}-06$ & $3,26 \mathrm{E}-03$ & 7,93E-03 & $1,53 \mathrm{E}-02$ \\
\hline GFSA3 & $1,50 \mathrm{E}-07$ & $1,62 \mathrm{E}-05$ & $5,81 \mathrm{E}-06$ & $2,00 \mathrm{E}-02$ & $2,47 \mathrm{E}-02$ & $1,27 \mathrm{E}-02$ \\
\hline GGBR4 & $1,60 \mathrm{E}-07$ & 9,69E-06 & $7,20 \mathrm{E}-07$ & $1,86 \mathrm{E}-02$ & $3,30 \mathrm{E}-02$ & $4,32 \mathrm{E}-02$ \\
\hline GOAU4 & $1,40 \mathrm{E}-07$ & $1,20 \mathrm{E}-04$ & $6,90 \mathrm{E}-07$ & $2,08 \mathrm{E}-02$ & $6,29 \mathrm{E}-03$ & 4,39E-02 \\
\hline GOLL4 & $1,90 \mathrm{E}-07$ & $9,37 \mathrm{E}-05$ & $1,02 \mathrm{E}-05$ & $1,72 \mathrm{E}-02$ & 7,63E-03 & $8,61 \mathrm{E}-03$ \\
\hline ITSA4 & $1,50 \mathrm{E}-07$ & $9,15 \mathrm{E}-06$ & 1,11E-06 & $1,96 \mathrm{E}-02$ & $3,41 \mathrm{E}-02$ & $3,44 \mathrm{E}-02$ \\
\hline ITUB4 & $1,70 \mathrm{E}-07$ & $7,26 \mathrm{E}-06$ & $1,03 \mathrm{E}-06$ & 1,81E-02 & $3,86 \mathrm{E}-02$ & $3,57 \mathrm{E}-02$ \\
\hline JBSS3 & $1,69 \mathrm{E}-06$ & $8,91 \mathrm{E}-05$ & $1,28 \mathrm{E}-06$ & $3,79 \mathrm{E}-03$ & 7,93E-03 & $3,18 \mathrm{E}-02$ \\
\hline KLBN4 & $9,80 \mathrm{E}-07$ & $5,86 \mathrm{E}-02$ & $4,50 \mathrm{E}-07$ & $5,74 \mathrm{E}-03$ & 7,70E-07 & $5,45 \mathrm{E}-02$ \\
\hline LAME4 & $2,53 \mathrm{E}-06$ & $9,37 \mathrm{E}-05$ & $1,99 \mathrm{E}-05$ & $2,74 \mathrm{E}-03$ & 7,63E-03 & $5,17 \mathrm{E}-03$ \\
\hline LIGT3 & $1,10 \mathrm{E}-07$ & $6,55 \mathrm{E}-05$ & $5,82 \mathrm{E}-06$ & $2,31 \mathrm{E}-02$ & 9,94E-03 & $1,27 \mathrm{E}-02$ \\
\hline
\end{tabular}


Table 1. Continued...

\begin{tabular}{|c|c|c|c|c|c|c|}
\hline \multirow[t]{2}{*}{ Title } & \multicolumn{3}{|c|}{ Probability of maximization } & \multicolumn{3}{|c|}{ Probability of minimization } \\
\hline & $\mathrm{P} / \mathrm{E}$ & Inverted \% & MAX/MIN & $\mathrm{P} / \mathrm{E}$ & Inverted \% & MAX/MIN \\
\hline LREN3 & $3,60 \mathrm{E}-07$ & $1,53 \mathrm{E}-05$ & $6,90 \mathrm{E}-07$ & $1,15 \mathrm{E}-02$ & $2,55 \mathrm{E}-02$ & 4,39E-02 \\
\hline MRFG3 & $3,20 \mathrm{E}-07$ & $3,30 \mathrm{E}-04$ & $3,68 \mathrm{E}-05$ & $1,24 \mathrm{E}-02$ & $2,66 \mathrm{E}-03$ & $3,10 \mathrm{E}-03$ \\
\hline MRVE3 & $1,50 \mathrm{E}-07$ & 4,79E-05 & 2,09E-06 & $1,95 \mathrm{E}-02$ & $1,24 \mathrm{E}-02$ & 2,41E-02 \\
\hline NATU3 & $5,50 \mathrm{E}-07$ & $7,64 \mathrm{E}-05$ & $1,70 \mathrm{E}-07$ & $8,68 \mathrm{E}-03$ & $8,88 \mathrm{E}-03$ & $8,40 \mathrm{E}-02$ \\
\hline PCAR5 & $9,70 \mathrm{E}-07$ & $2,13 \mathrm{E}-05$ & $3,86 \mathrm{E}-06$ & $5,80 \mathrm{E}-03$ & $2,09 \mathrm{E}-02$ & $1,66 \mathrm{E}-02$ \\
\hline PDGR3 & $1,60 \mathrm{E}-07$ & $9,15 \mathrm{E}-06$ & 4,04E-04 & $1,93 \mathrm{E}-02$ & $3,41 \mathrm{E}-02$ & $2,50 \mathrm{E}-04$ \\
\hline PETR3 & $1,00 \mathrm{E}-07$ & $9,69 \mathrm{E}-06$ & $2,10 \mathrm{E}-05$ & $2,44 \mathrm{E}-02$ & $3,30 \mathrm{E}-02$ & $4,97 \mathrm{E}-03$ \\
\hline PETR4 & $1,00 \mathrm{E}-07$ & $6,09 \mathrm{E}-06$ & $1,73 \mathrm{E}-06$ & $2,54 \mathrm{E}-02$ & $4,23 \mathrm{E}-02$ & 2,69E-02 \\
\hline RDCD3 & $1,20 \mathrm{E}-07$ & $3,67 \mathrm{E}-05$ & $8,92 \mathrm{E}-06$ & $2,29 \mathrm{E}-02$ & $1,48 \mathrm{E}-02$ & $9,47 \mathrm{E}-03$ \\
\hline RSID3 & $1,30 \mathrm{E}-07$ & $3,67 \mathrm{E}-05$ & $5,14 \mathrm{E}-05$ & $2,13 \mathrm{E}-02$ & $1,48 \mathrm{E}-02$ & 2,31E-03 \\
\hline SANB11 & $3,40 \mathrm{E}-07$ & $7,64 \mathrm{E}-05$ & $1,30 \mathrm{E}-05$ & $1,19 \mathrm{E}-02$ & $8,88 \mathrm{E}-03$ & $7,20 \mathrm{E}-03$ \\
\hline SBSP3 & $9,00 \mathrm{E}-08$ & $2,65 \mathrm{E}-03$ & $5,50 \mathrm{E}-07$ & $2,63 \mathrm{E}-02$ & $2,63 \mathrm{E}-04$ & 4,94E-02 \\
\hline TAMM4 & $1,10 \mathrm{E}-07$ & $1,27 \mathrm{E}-04$ & $5,12 \mathrm{E}-05$ & 2,34E-02 & $6,04 \mathrm{E}-03$ & 2,31E-03 \\
\hline TCSL3 & $8,00 \mathrm{E}-07$ & $7,25 \mathrm{E}-01$ & $1,18 \mathrm{E}-02$ & $6,64 \mathrm{E}-03$ & $1,00 \mathrm{E}-08$ & $7,20 \mathrm{E}-07$ \\
\hline TCSL4 & 4,90E-07 & $6,22 \mathrm{E}-05$ & $3,31 \mathrm{E}-04$ & $9,38 \mathrm{E}-03$ & $1,03 \mathrm{E}-02$ & $3,21 \mathrm{E}-04$ \\
\hline TLPP4 & $1,10 \mathrm{E}-07$ & 2,77E-02 & $3,05 \mathrm{E}-06$ & $2,35 \mathrm{E}-02$ & $4,73 \mathrm{E}-06$ & $1,92 \mathrm{E}-02$ \\
\hline TMAR5 & $1,20 \mathrm{E}-07$ & 4,36E-02 & $9,98 \mathrm{E}-05$ & $2,23 \mathrm{E}-02$ & $1,64 \mathrm{E}-06$ & $1,22 \mathrm{E}-03$ \\
\hline TNLP3 & $1,60 \mathrm{E}-07$ & $1,17 \mathrm{E}-01$ & $1,53 \mathrm{E}-05$ & $1,87 \mathrm{E}-02$ & $1,00 \mathrm{E}-07$ & $6,35 \mathrm{E}-03$ \\
\hline TNLP4 & $1,20 \mathrm{E}-07$ & $1,62 \mathrm{E}-05$ & $5,08 \mathrm{E}-04$ & $2,21 \mathrm{E}-02$ & $2,47 \mathrm{E}-02$ & $1,86 \mathrm{E}-04$ \\
\hline TRPL4 & $1,30 \mathrm{E}-07$ & 7,09E-04 & $2,73 \mathrm{E}-06$ & $2,11 \mathrm{E}-02$ & $1,25 \mathrm{E}-03$ & $2,06 \mathrm{E}-02$ \\
\hline UGPA4 & $3,30 \mathrm{E}-07$ & $6,55 \mathrm{E}-05$ & $2,60 \mathrm{E}-07$ & $1,22 \mathrm{E}-02$ & $9,94 \mathrm{E}-03$ & $7,05 \mathrm{E}-02$ \\
\hline USIM3 & $1,70 \mathrm{E}-07$ & 1,99E-02 & $1,68 \mathrm{E}-04$ & $1,86 \mathrm{E}-02$ & $9,53 \mathrm{E}-06$ & 7,04E-04 \\
\hline USIM5 & $1,40 \mathrm{E}-07$ & $8,64 \mathrm{E}-06$ & $3,10 \mathrm{E}-05$ & $2,03 \mathrm{E}-02$ & $3,52 \mathrm{E}-02$ & $3,60 \mathrm{E}-03$ \\
\hline VALE3 & $1,70 \mathrm{E}-07$ & 7,69E-06 & $1,30 \mathrm{E}-06$ & $1,84 \mathrm{E}-02$ & $3,74 \mathrm{E}-02$ & $3,15 \mathrm{E}-02$ \\
\hline VALE5 & $1,40 \mathrm{E}-07$ & 6,09E-06 & $1,43 \mathrm{E}-06$ & $2,01 \mathrm{E}-02$ & 4,23E-02 & 2,99E-02 \\
\hline VIVO4 & $2,40 \mathrm{E}-07$ & 4,31E-05 & $2,44 \mathrm{E}-05$ & $1,49 \mathrm{E}-02$ & 1,33E-02 & 4,40E-03 \\
\hline
\end{tabular}

criterion. Table 2 presents the joint probabilities of maximizing and minimizing according to all and according to at least one of the criteria and the rankings derived from each of these approaches.

It can be seen in Table 2 that the stock selected to be sold by maximizing the joint probability of maximizing the three scores together is TCSL3, while the approach based on the probability of maximizing at least one score would select CESP6. Though CESP6 is ranked second in the unanimity approach and TCSL3 is ranked third if at least one is enough, there are stronger contradictions among the first options to sell. For instance, SBSP3 is ranked $9^{\text {th }}$ by the 'at least one' approach and $35^{\text {th }}$ by the 'unanimity' approach.

The same happens with the decision on purchasing. The stock that maximizes the joint probability of minimizing the three scores is PETR4, which is ranked third if 
Table 2. Joint probabilities of maximizing and of minimizing the 3 scores.

\begin{tabular}{|c|c|c|c|c|c|c|c|c|}
\hline \multirow[t]{2}{*}{ Title } & \multicolumn{2}{|c|}{$\begin{array}{l}\text { Joint minimization } \\
\text { all }\end{array}$} & \multicolumn{2}{|c|}{$\begin{array}{c}\text { Joint minimization } \\
\text { one }\end{array}$} & \multicolumn{2}{|c|}{$\begin{array}{l}\text { Joint maximization } \\
\text { all }\end{array}$} & \multicolumn{2}{|c|}{$\begin{array}{c}\text { Joint maximization } \\
\text { one }\end{array}$} \\
\hline & Probability & Rank & Probability & Rank & Probability & Rank & Probability & Rank \\
\hline ALLL3 & $1,48 \mathrm{E}-13$ & 8 & 4,68E-04 & 14 & 2,91E-09 & 52 & 1,59E-02 & 58 \\
\hline AMBV4 & $9,8 \mathrm{E}-16$ & 19 & 3,09E-04 & 20 & $1,44 \mathrm{E}-07$ & 45 & $4,43 \mathrm{E}-02$ & 31 \\
\hline BBAS3 & $2,35 \mathrm{E}-18$ & 54 & 1,17E-05 & 54 & $1,77 \mathrm{E}-05$ & 8 & $7,84 \mathrm{E}-02$ & 11 \\
\hline BBDC4 & $4,29 \mathrm{E}-18$ & 52 & $1,21 \mathrm{E}-05$ & 53 & $1,27 \mathrm{E}-05$ & 10 & $7,15 \mathrm{E}-02$ & 13 \\
\hline BISA3 & $1,54 \mathrm{E}-15$ & 16 & $6,40 \mathrm{E}-04$ & 12 & 1,69E-07 & 43 & $2,77 \mathrm{E}-02$ & 49 \\
\hline BRFS3 & $1,07 \mathrm{E}-15$ & 17 & $3,44 \mathrm{E}-05$ & 44 & $2,37 \mathrm{E}-07$ & 42 & $3,53 \mathrm{E}-02$ & 41 \\
\hline BRTO4 & $4,75 \mathrm{E}-15$ & 12 & $4,65 \mathrm{E}-04$ & 15 & $4,43 \mathrm{E}-08$ & 50 & $3,01 \mathrm{E}-02$ & 47 \\
\hline BTOW3 & $3,7 \mathrm{E}-11$ & 3 & $1,92 \mathrm{E}-03$ & 10 & $3,54 \mathrm{E}-12$ & 58 & $3,84 \mathrm{E}-03$ & 61 \\
\hline BVMF3 & $9,9 \mathrm{E}-18$ & 49 & $1,17 \mathrm{E}-05$ & 55 & $7,43 \mathrm{E}-06$ & 12 & $6,49 \mathrm{E}-02$ & 15 \\
\hline CCRO3 & $8,06 \mathrm{E}-16$ & 20 & 1,61E-04 & 25 & $4,05 \mathrm{E}-07$ & 37 & 2,34E-02 & 54 \\
\hline CESP6 & $1,11 \mathrm{E}-10$ & 2 & $9,99 \mathrm{E}-01$ & 1 & $2,61 \mathrm{E}-12$ & 60 & $4,07 \mathrm{E}-02$ & 37 \\
\hline CIEL3 & $2,89 \mathrm{E}-17$ & 42 & $3,12 \mathrm{E}-05$ & 45 & $3,66 \mathrm{E}-06$ & 20 & $5,32 \mathrm{E}-02$ & 22 \\
\hline CMIG4 & $1,43 \mathrm{E}-18$ & 57 & $1,69 \mathrm{E}-05$ & 51 & $2,32 \mathrm{E}-05$ & 5 & 8,87E-02 & 7 \\
\hline CPFE3 & $8,63 \mathrm{E}-17$ & 36 & 2,29E-04 & 21 & $1,6 \mathrm{E}-06$ & 26 & 4,47E-02 & 30 \\
\hline CPLE6 & $1,6 \mathrm{E}-17$ & 45 & 2,77E-05 & 47 & $5,94 \mathrm{E}-06$ & 15 & $5,34 \mathrm{E}-02$ & 21 \\
\hline CRUZ3 & $6,6 \mathrm{E}-16$ & 23 & 9,69E-05 & 30 & 4,19E-07 & 36 & $2,70 \mathrm{E}-02$ & 50 \\
\hline CSAN3 & $2,78 \mathrm{E}-16$ & 27 & $8,72 \mathrm{E}-05$ & 35 & $7,91 \mathrm{E}-07$ & 32 & $3,20 \mathrm{E}-02$ & 45 \\
\hline CSNA3 & $2,09 \mathrm{E}-17$ & 43 & $2,27 \mathrm{E}-05$ & 49 & 4,79E-06 & 18 & $5,27 \mathrm{E}-02$ & 24 \\
\hline CYRE3 & $1,61 \mathrm{E}-16$ & 33 & $7,53 \mathrm{E}-05$ & 37 & $9,47 \mathrm{E}-07$ & 30 & 4,31E-02 & 33 \\
\hline DTEX3 & $1,58 \mathrm{E}-16$ & 34 & $1,82 \mathrm{E}-04$ & 23 & $1,14 \mathrm{E}-06$ & 27 & $3,58 \mathrm{E}-02$ & 40 \\
\hline ELET3 & $4,45 \mathrm{E}-16$ & 25 & 2,04E-04 & 22 & $3,17 \mathrm{E}-07$ & 41 & 4,48E-02 & 29 \\
\hline ELET6 & $2,54 \mathrm{E}-15$ & 15 & $3,42 \mathrm{E}-04$ & 19 & $8,32 \mathrm{E}-08$ & 49 & 3,23E-02 & 43 \\
\hline ELPL4 & $4,14 \mathrm{E}-17$ & 39 & $1,09 \mathrm{E}-04$ & 28 & $2,77 \mathrm{E}-06$ & 23 & 4,97E-02 & 25 \\
\hline EMBR3 & $4,21 \mathrm{E}-12$ & 4 & $9,85 \mathrm{E}-01$ & 2 & $3,48 \mathrm{E}-12$ & 59 & $3,81 \mathrm{E}-02$ & 38 \\
\hline FIBR3 & $8,02 \mathrm{E}-16$ & 21 & $9,55 \mathrm{E}-05$ & 31 & $3,96 \mathrm{E}-07$ & 38 & 2,63E-02 & 51 \\
\hline GFSA3 & $1,41 \mathrm{E}-17$ & 47 & $2,21 \mathrm{E}-05$ & 50 & $6,28 \mathrm{E}-06$ & 14 & 5,63E-02 & 19 \\
\hline GGBR4 & $1,12 \mathrm{E}-18$ & 60 & $1,06 \mathrm{E}-05$ & 56 & $2,66 \mathrm{E}-05$ & 2 & $9,21 \mathrm{E}-02$ & 2 \\
\hline GOAU4 & $1,16 \mathrm{E}-17$ & 48 & $1,21 \mathrm{E}-04$ & 26 & 5,74E-06 & 17 & $6,97 \mathrm{E}-02$ & 14 \\
\hline GOLL4 & $1,81 \mathrm{E}-16$ & 32 & $1,04 \mathrm{E}-04$ & 29 & $1,13 \mathrm{E}-06$ & 28 & $3,31 \mathrm{E}-02$ & 42 \\
\hline ITSA4 & $1,52 \mathrm{E}-18$ & 56 & $1,04 \mathrm{E}-05$ & 57 & $2,3 \mathrm{E}-05$ & 6 & $8,56 \mathrm{E}-02$ & 8 \\
\hline ITUB4 & $1,27 \mathrm{E}-18$ & 58 & $8,46 \mathrm{E}-06$ & 59 & 2,49E-05 & 4 & 8,97E-02 & 5 \\
\hline JBSS3 & $1,93 \mathrm{E}-16$ & 31 & $9,20 \mathrm{E}-05$ & 32 & $9,56 \mathrm{E}-07$ & 29 & 4,31E-02 & 32 \\
\hline KLBN4 & $2,59 \mathrm{E}-14$ & 9 & $5,86 \mathrm{E}-02$ & 5 & $2,41 \mathrm{E}-10$ & 54 & $5,99 \mathrm{E}-02$ & 17 \\
\hline LAME4 & $4,73 \mathrm{E}-15$ & 13 & $1,16 \mathrm{E}-04$ & 27 & $1,08 \mathrm{E}-07$ & 46 & $1,55 \mathrm{E}-02$ & 59 \\
\hline LIGT3 & $4,19 \mathrm{E}-17$ & 38 & $7,14 \mathrm{E}-05$ & 38 & 2,91E-06 & 22 & $4,51 \mathrm{E}-02$ & 28 \\
\hline
\end{tabular}


Table 2. Continued...

\begin{tabular}{|c|c|c|c|c|c|c|c|c|}
\hline LREN3 & $3,8 \mathrm{E}-18$ & 53 & $1,63 \mathrm{E}-05$ & 52 & $1,29 \mathrm{E}-05$ & 9 & $7,90 \mathrm{E}-02$ & 10 \\
\hline MRFG3 & $3,89 \mathrm{E}-15$ & 14 & $3,67 \mathrm{E}-04$ & 18 & $1,02 \mathrm{E}-07$ & 47 & $1,81 \mathrm{E}-02$ & 57 \\
\hline MRVE3 & $1,5 \mathrm{E}-17$ & 46 & $5,01 \mathrm{E}-05$ & 41 & $5,82 \mathrm{E}-06$ & 16 & $5,50 \mathrm{E}-02$ & 20 \\
\hline NATU3 & $7,15 \mathrm{E}-18$ & 50 & $7,72 \mathrm{E}-05$ & 36 & $6,48 \mathrm{E}-06$ & 13 & $1,00 \mathrm{E}-01$ & 1 \\
\hline PCAR5 & $7,99 \mathrm{E}-17$ & 37 & $2,62 \mathrm{E}-05$ & 48 & $2,02 \mathrm{E}-06$ & 25 & $4,28 \mathrm{E}-02$ & 34 \\
\hline PDGR3 & $5,92 \mathrm{E}-16$ & 24 & $4,14 \mathrm{E}-04$ & 16 & $1,64 \mathrm{E}-07$ & 44 & $5,29 \mathrm{E}-02$ & 23 \\
\hline PETR3 & $2,03 \mathrm{E}-17$ & 44 & $3,08 \mathrm{E}-05$ & 46 & $4 \mathrm{E}-06$ & 19 & $6,13 \mathrm{E}-02$ & 16 \\
\hline PETR4 & $1,05 \mathrm{E}-18$ & 61 & $7,92 \mathrm{E}-06$ & 60 & $2,9 \mathrm{E}-05$ & 1 & $9,18 \mathrm{E}-02$ & 3 \\
\hline RDCD3 & $3,93 \mathrm{E}-17$ & 40 & $4,58 \mathrm{E}-05$ & 42 & $3,21 \mathrm{E}-06$ & 21 & $4,65 \mathrm{E}-02$ & 26 \\
\hline RSID3 & $2,45 \mathrm{E}-16$ & 30 & $8,83 \mathrm{E}-05$ & 34 & $7,27 \mathrm{E}-07$ & 34 & $3,80 \mathrm{E}-02$ & 39 \\
\hline SANB11 & $3,38 \mathrm{E}-16$ & 26 & $8,98 \mathrm{E}-05$ & 33 & $7,58 \mathrm{E}-07$ & 33 & $2,77 \mathrm{E}-02$ & 48 \\
\hline SBSP3 & $1,31 \mathrm{E}-16$ & 35 & $2,65 \mathrm{E}-03$ & 9 & $3,42 \mathrm{E}-07$ & 39 & $7,47 \mathrm{E}-02$ & 12 \\
\hline TAMM4 & $7,13 \mathrm{E}-16$ & 22 & $1,78 \mathrm{E}-04$ & 24 & $3,27 \mathrm{E}-07$ & 40 & $3,15 \mathrm{E}-02$ & 46 \\
\hline TCSL3 & $6,85 \mathrm{E}-09$ & 1 & $7,29 \mathrm{E}-01$ & 3 & $4,78 \mathrm{E}-17$ & 61 & $6,64 \mathrm{E}-03$ & 60 \\
\hline TCSL4 & $1,01 \mathrm{E}-14$ & 10 & $3,94 \mathrm{E}-04$ & 17 & $3,1 \mathrm{E}-08$ & 51 & $1,99 \mathrm{E}-02$ & 55 \\
\hline TLPP4 & $9,29 \mathrm{E}-15$ & 11 & $2,77 \mathrm{E}-02$ & 7 & $2,14 \mathrm{E}-09$ & 53 & $4,23 \mathrm{E}-02$ & 36 \\
\hline TMAR5 & $5,23 \mathrm{E}-13$ & 6 & $4,37 \mathrm{E}-02$ & 6 & $4,45 \mathrm{E}-11$ & 56 & $2,35 \mathrm{E}-02$ & 53 \\
\hline TNLP3 & $2,87 \mathrm{E}-13$ & 7 & $1,17 \mathrm{E}-01$ & 4 & $1,19 \mathrm{E}-11$ & 57 & $2,49 \mathrm{E}-02$ & 52 \\
\hline TNLP4 & $9,85 \mathrm{E}-16$ & 18 & $5,24 \mathrm{E}-04$ & 13 & $1,01 \mathrm{E}-07$ & 48 & $4,64 \mathrm{E}-02$ & 27 \\
\hline TRPL4 & $2,52 \mathrm{E}-16$ & 29 & $7,12 \mathrm{E}-04$ & 11 & $5,43 \mathrm{E}-07$ & 35 & $4,25 \mathrm{E}-02$ & 35 \\
\hline UGPA4 & $5,62 \mathrm{E}-18$ & 51 & $6,61 \mathrm{E}-05$ & 40 & $8,58 \mathrm{E}-06$ & 11 & $9,10 \mathrm{E}-02$ & 4 \\
\hline USIM3 & $5,67 \mathrm{E}-13$ & 5 & $2,00 \mathrm{E}-02$ & 8 & $1,25 \mathrm{E}-10$ & 55 & $1,93 \mathrm{E}-02$ & 56 \\
\hline USIM5 & $3,75 \mathrm{E}-17$ & 41 & $3,97 \mathrm{E}-05$ & 43 & $2,57 \mathrm{E}-06$ & 24 & $5,82 \mathrm{E}-02$ & 18 \\
\hline VALE3 & $1,7 \mathrm{E}-18$ & 55 & $9,16 \mathrm{E}-06$ & 58 & $2,17 \mathrm{E}-05$ & 7 & $8,50 \mathrm{E}-02$ & 9 \\
\hline VALE5 & $1,22 \mathrm{E}-18$ & 59 & $7,66 \mathrm{E}-06$ & 61 & $2,55 \mathrm{E}-05$ & 3 & $8,96 \mathrm{E}-02$ & 6 \\
\hline VIVO4 & $2,52 \mathrm{E}-16$ & 28 & $6,77 \mathrm{E}-05$ & 39 & $8,7 \mathrm{E}-07$ & 31 & $3,22 \mathrm{E}-02$ & 44 \\
\hline
\end{tabular}

the approach based on selecting by the probability of minimizing at least one is taken. But this last approach would lead to select NATU3, which is ranked only $13^{\text {th }}$ by the unanimity approach.

With 61 entries in each vector, other methodologies would difficultly notice the pattern revealed by the probabilistic transformation, as, for every criterion, only a few shares do not present very low probabilities of maximization. This reflects in the contradictory ranks of NATU3 and SBSP3.

A way to deal with these contradictions comes from the fact that, after some point, very large or very low values in the criteria considered did not matter for a set of highly negotiated stocks as those chosen to form the portfolio considered. This suggests truncation of the data. Trimming was performed at the first and third quartile of each vector. The result of that is presented in Tables 3 and 4. The probabilities of minimization and maximization according to each criterion separately are presented in 
Table 3. Probabilities for truncated separate evaluations.

\begin{tabular}{|c|c|c|c|c|c|c|}
\hline \multirow[t]{2}{*}{ Title } & \multicolumn{3}{|c|}{ Probability of maximization } & \multicolumn{3}{|c|}{ Probability of minimization } \\
\hline & $\mathrm{P} / \mathrm{E}$ & Inverted \% & MAX/MIN & $\mathrm{P} / \mathrm{E}$ & Inverted \% & MAX/MIN \\
\hline ALLL3 & $5,20 \mathrm{E}-02$ & $1,38 \mathrm{E}-03$ & $4,96 \mathrm{E}-02$ & $3,55 \mathrm{E}-05$ & $4,78 \mathrm{E}-03$ & $4,03 \mathrm{E}-05$ \\
\hline AMBV4 & $3,78 \mathrm{E}-02$ & 5,59E-05 & 4,96E-02 & $6,55 \mathrm{E}-05$ & 4,33E-02 & $4,03 \mathrm{E}-05$ \\
\hline BBAS3 & $6,82 \mathrm{E}-05$ & 5,59E-05 & $1,02 \mathrm{E}-04$ & $3,85 \mathrm{E}-02$ & $4,33 \mathrm{E}-02$ & $3,05 \mathrm{E}-02$ \\
\hline BBDC4 & $2,12 \mathrm{E}-04$ & $5,59 \mathrm{E}-05$ & $1,32 \mathrm{E}-04$ & $1,95 \mathrm{E}-02$ & $4,33 \mathrm{E}-02$ & $2,61 \mathrm{E}-02$ \\
\hline BISA3 & $1,05 \mathrm{E}-04$ & $4,63 \mathrm{E}-02$ & $8,59 \mathrm{E}-03$ & $3,01 \mathrm{E}-02$ & 4,91E-05 & $6,54 \mathrm{E}-04$ \\
\hline BRFS3 & $5,20 \mathrm{E}-02$ & $1,33 \mathrm{E}-04$ & $6,79 \mathrm{E}-04$ & $3,55 \mathrm{E}-05$ & $2,65 \mathrm{E}-02$ & $8,40 \mathrm{E}-03$ \\
\hline BRTO4 & $6,82 \mathrm{E}-05$ & 4,63E-02 & $4,96 \mathrm{E}-02$ & $3,85 \mathrm{E}-02$ & 4,91E-05 & $4,03 \mathrm{E}-05$ \\
\hline BTOW3 & $5,20 \mathrm{E}-02$ & 4,63E-02 & $4,96 \mathrm{E}-02$ & $3,55 \mathrm{E}-05$ & 4,91E-05 & $4,03 \mathrm{E}-05$ \\
\hline BVMF3 & $5,20 \mathrm{E}-02$ & $5,59 \mathrm{E}-05$ & $1,77 \mathrm{E}-04$ & $3,55 \mathrm{E}-05$ & $4,33 \mathrm{E}-02$ & $2,18 \mathrm{E}-02$ \\
\hline CCRO3 & $5,20 \mathrm{E}-02$ & 4,63E-02 & $8,47 \mathrm{E}-04$ & $3,55 \mathrm{E}-05$ & 4,91E-05 & 7,03E-03 \\
\hline CESP6 & $5,20 \mathrm{E}-02$ & $5,59 \mathrm{E}-05$ & $3,23 \mathrm{E}-03$ & $3,55 \mathrm{E}-05$ & $4,33 \mathrm{E}-02$ & $2,03 \mathrm{E}-03$ \\
\hline CIEL3 & $6,82 \mathrm{E}-05$ & $6,97 \mathrm{E}-05$ & 5,91E-03 & $3,85 \mathrm{E}-02$ & $3,84 \mathrm{E}-02$ & $1,04 \mathrm{E}-03$ \\
\hline CMIG4 & $1,38 \mathrm{E}-04$ & 6,97E-05 & $5,09 \mathrm{E}-05$ & $2,55 \mathrm{E}-02$ & $3,84 \mathrm{E}-02$ & 4,47E-02 \\
\hline CPFE3 & $3,22 \mathrm{E}-04$ & 4,63E-02 & $5,09 \mathrm{E}-05$ & $1,47 \mathrm{E}-02$ & 4,91E-05 & $4,47 \mathrm{E}-02$ \\
\hline CPLE6 & $8,27 \mathrm{E}-04$ & $3,04 \mathrm{E}-04$ & $1,83 \mathrm{E}-04$ & $7,18 \mathrm{E}-03$ & $1,56 \mathrm{E}-02$ & $2,13 \mathrm{E}-02$ \\
\hline CRUZ3 & $2,12 \mathrm{E}-02$ & $5,24 \mathrm{E}-03$ & 4,44E-02 & $1,77 \mathrm{E}-04$ & $1,24 \mathrm{E}-03$ & $5,00 \mathrm{E}-05$ \\
\hline CSAN3 & $9,45 \mathrm{E}-04$ & 7,13E-03 & $1,74 \mathrm{E}-02$ & $6,43 \mathrm{E}-03$ & $8,63 \mathrm{E}-04$ & $2,46 \mathrm{E}-04$ \\
\hline CSNA3 & 1,49E-03 & 5,59E-05 & $1,05 \mathrm{E}-03$ & $4,32 \mathrm{E}-03$ & $4,33 \mathrm{E}-02$ & $5,86 \mathrm{E}-03$ \\
\hline CYRE3 & $1,22 \mathrm{E}-04$ & 2,02E-04 & 4,96E-02 & $2,76 \mathrm{E}-02$ & $2,04 \mathrm{E}-02$ & $4,03 \mathrm{E}-05$ \\
\hline DTEX3 & $4,66 \mathrm{E}-03$ & $4,63 \mathrm{E}-02$ & $2,28 \mathrm{E}-04$ & $1,35 \mathrm{E}-03$ & 4,91E-05 & $1,85 \mathrm{E}-02$ \\
\hline ELET3 & $6,82 \mathrm{E}-05$ & 5,47E-04 & 4,96E-02 & $3,85 \mathrm{E}-02$ & $1,02 \mathrm{E}-02$ & $4,03 \mathrm{E}-05$ \\
\hline ELET6 & $6,82 \mathrm{E}-05$ & $3,23 \mathrm{E}-02$ & 4,96E-02 & $3,85 \mathrm{E}-02$ & $9,51 \mathrm{E}-05$ & $4,03 \mathrm{E}-05$ \\
\hline ELPL4 & $6,82 \mathrm{E}-05$ & $2,85 \mathrm{E}-02$ & $5,79 \mathrm{E}-04$ & $3,85 \mathrm{E}-02$ & $1,18 \mathrm{E}-04$ & $9,51 \mathrm{E}-03$ \\
\hline EMBR3 & $8,60 \mathrm{E}-03$ & $8,68 \mathrm{E}-05$ & 4,96E-02 & $6,44 \mathrm{E}-04$ & $3,40 \mathrm{E}-02$ & 4,03E-05 \\
\hline FIBR3 & $5,20 \mathrm{E}-02$ & 1,93E-02 & $2,87 \mathrm{E}-04$ & $3,55 \mathrm{E}-05$ & $2,21 \mathrm{E}-04$ & $1,58 \mathrm{E}-02$ \\
\hline GFSA3 & $1,82 \mathrm{E}-04$ & $6,97 \mathrm{E}-05$ & $6,06 \mathrm{E}-04$ & $2,15 \mathrm{E}-02$ & $3,84 \mathrm{E}-02$ & $9,18 \mathrm{E}-03$ \\
\hline GGBR4 & 4,82E-04 & $5,59 \mathrm{E}-05$ & $5,09 \mathrm{E}-05$ & $1,10 \mathrm{E}-02$ & $4,33 \mathrm{E}-02$ & 4,47E-02 \\
\hline GOAU4 & $9,87 \mathrm{E}-05$ & 4,11E-02 & 5,09E-05 & $3,13 \mathrm{E}-02$ & $6,13 \mathrm{E}-05$ & 4,47E-02 \\
\hline GOLL4 & $1,33 \mathrm{E}-03$ & $2,20 \mathrm{E}-02$ & $2,46 \mathrm{E}-03$ & 4,79E-03 & 1,79E-04 & $2,69 \mathrm{E}-03$ \\
\hline ITSA4 & $2,34 \mathrm{E}-04$ & 5,59E-05 & $5,09 \mathrm{E}-05$ & $1,83 \mathrm{E}-02$ & $4,33 \mathrm{E}-02$ & 4,47E-02 \\
\hline ITUB4 & 7,09E-04 & $5,59 \mathrm{E}-05$ & $5,09 \mathrm{E}-05$ & $8,14 \mathrm{E}-03$ & $4,33 \mathrm{E}-02$ & 4,47E-02 \\
\hline JBSS3 & $5,20 \mathrm{E}-02$ & $1,93 \mathrm{E}-02$ & $5,09 \mathrm{E}-05$ & $3,55 \mathrm{E}-05$ & $2,21 \mathrm{E}-04$ & $4,47 \mathrm{E}-02$ \\
\hline KLBN4 & $5,20 \mathrm{E}-02$ & 4,63E-02 & $5,09 \mathrm{E}-05$ & $3,55 \mathrm{E}-05$ & 4,91E-05 & 4,47E-02 \\
\hline LAME4 & $5,20 \mathrm{E}-02$ & $2,20 \mathrm{E}-02$ & $1,11 \mathrm{E}-02$ & $3,55 \mathrm{E}-05$ & $1,79 \mathrm{E}-04$ & 4,67E-04 \\
\hline LIGT3 & $6,82 \mathrm{E}-05$ & $8,28 \mathrm{E}-03$ & $6,08 \mathrm{E}-04$ & $3,85 \mathrm{E}-02$ & $7,16 \mathrm{E}-04$ & $9,17 \mathrm{E}-03$ \\
\hline
\end{tabular}


Table 3. Continued...

\begin{tabular}{|c|c|c|c|c|c|c|}
\hline \multirow[t]{2}{*}{ Title } & \multicolumn{3}{|c|}{ Probability of maximization } & \multicolumn{3}{|c|}{ Probability of minimization } \\
\hline & $\mathrm{P} / \mathrm{E}$ & Inverted $\%$ & MAX/MIN & $\mathrm{P} / \mathrm{E}$ & Inverted \% & MAX/MIN \\
\hline LREN3 & $5,20 \mathrm{E}-02$ & $5,59 \mathrm{E}-05$ & 5,09E-05 & $3,55 \mathrm{E}-05$ & $4,33 \mathrm{E}-02$ & 4,47E-02 \\
\hline MRFG3 & $3,65 \mathrm{E}-02$ & $4,63 \mathrm{E}-02$ & 3,72E-02 & $6,99 \mathrm{E}-05$ & 4,91E-05 & $6,96 \mathrm{E}-05$ \\
\hline MRVE3 & $2,57 \mathrm{E}-04$ & $3,24 \mathrm{E}-03$ & $5,09 \mathrm{E}-05$ & $1,71 \mathrm{E}-02$ & $2,10 \mathrm{E}-03$ & $4,47 \mathrm{E}-02$ \\
\hline NATU3 & $5,20 \mathrm{E}-02$ & $1,28 \mathrm{E}-02$ & $5,09 \mathrm{E}-05$ & $3,55 \mathrm{E}-05$ & $4,02 \mathrm{E}-04$ & $4,47 \mathrm{E}-02$ \\
\hline PCAR5 & $5,20 \mathrm{E}-02$ & $2,02 \mathrm{E}-04$ & $2,01 \mathrm{E}-04$ & $3,55 \mathrm{E}-05$ & $2,04 \mathrm{E}-02$ & $2,00 \mathrm{E}-02$ \\
\hline PDGR3 & $3,02 \mathrm{E}-04$ & $5,59 \mathrm{E}-05$ & 4,96E-02 & $1,54 \mathrm{E}-02$ & 4,33E-02 & $4,03 \mathrm{E}-05$ \\
\hline PETR3 & $6,82 \mathrm{E}-05$ & $5,59 \mathrm{E}-05$ & $1,23 \mathrm{E}-02$ & $3,85 \mathrm{E}-02$ & $4,33 \mathrm{E}-02$ & $4,04 \mathrm{E}-04$ \\
\hline PETR4 & $6,82 \mathrm{E}-05$ & $5,59 \mathrm{E}-05$ & $5,09 \mathrm{E}-05$ & $3,85 \mathrm{E}-02$ & 4,33E-02 & 4,47E-02 \\
\hline RDCD3 & $6,82 \mathrm{E}-05$ & $1,38 \mathrm{E}-03$ & 1,79E-03 & $3,85 \mathrm{E}-02$ & $4,78 \mathrm{E}-03$ & $3,66 \mathrm{E}-03$ \\
\hline RSID3 & $6,82 \mathrm{E}-05$ & $1,38 \mathrm{E}-03$ & $4,96 \mathrm{E}-02$ & $3,85 \mathrm{E}-02$ & $4,78 \mathrm{E}-03$ & $4,03 \mathrm{E}-05$ \\
\hline SANB11 & $5,20 \mathrm{E}-02$ & $1,28 \mathrm{E}-02$ & $4,34 \mathrm{E}-03$ & $3,55 \mathrm{E}-05$ & $4,02 \mathrm{E}-04$ & $1,48 \mathrm{E}-03$ \\
\hline SBSP3 & $6,82 \mathrm{E}-05$ & $4,63 \mathrm{E}-02$ & $5,09 \mathrm{E}-05$ & $3,85 \mathrm{E}-02$ & 4,91E-05 & $4,47 \mathrm{E}-02$ \\
\hline TAMM4 & $6,82 \mathrm{E}-05$ & 4,63E-02 & 4,96E-02 & $3,85 \mathrm{E}-02$ & 4,91E-05 & $4,03 \mathrm{E}-05$ \\
\hline TCSL3 & $5,20 \mathrm{E}-02$ & 4,63E-02 & 4,96E-02 & $3,55 \mathrm{E}-05$ & 4,91E-05 & $4,03 \mathrm{E}-05$ \\
\hline TCSL4 & $5,20 \mathrm{E}-02$ & 7,13E-03 & 4,96E-02 & $3,55 \mathrm{E}-05$ & $8,63 \mathrm{E}-04$ & $4,03 \mathrm{E}-05$ \\
\hline TLPP4 & $6,82 \mathrm{E}-05$ & $4,63 \mathrm{E}-02$ & $1,04 \mathrm{E}-04$ & $3,85 \mathrm{E}-02$ & 4,91E-05 & $3,00 \mathrm{E}-02$ \\
\hline TMAR5 & $6,82 \mathrm{E}-05$ & 4,63E-02 & $4,96 \mathrm{E}-02$ & $3,85 \mathrm{E}-02$ & 4,91E-05 & $4,03 \mathrm{E}-05$ \\
\hline TNLP3 & $4,65 \mathrm{E}-04$ & $4,63 \mathrm{E}-02$ & $6,28 \mathrm{E}-03$ & $1,12 \mathrm{E}-02$ & $4,91 \mathrm{E}-05$ & $9,65 \mathrm{E}-04$ \\
\hline TNLP4 & $6,82 \mathrm{E}-05$ & $6,97 \mathrm{E}-05$ & 4,96E-02 & $3,85 \mathrm{E}-02$ & $3,84 \mathrm{E}-02$ & $4,03 \mathrm{E}-05$ \\
\hline TRPL4 & 7,74E-05 & 4,63E-02 & $7,62 \mathrm{E}-05$ & $3,59 \mathrm{E}-02$ & 4,91E-05 & $3,59 \mathrm{E}-02$ \\
\hline UGPA4 & $4,05 \mathrm{E}-02$ & $8,28 \mathrm{E}-03$ & $5,09 \mathrm{E}-05$ & $5,76 \mathrm{E}-05$ & $7,16 \mathrm{E}-04$ & $4,47 \mathrm{E}-02$ \\
\hline USIM3 & $4,96 \mathrm{E}-04$ & 4,63E-02 & 4,96E-02 & $1,07 \mathrm{E}-02$ & 4,91E-05 & $4,03 \mathrm{E}-05$ \\
\hline USIM5 & $1,44 \mathrm{E}-04$ & $5,59 \mathrm{E}-05$ & $2,68 \mathrm{E}-02$ & $2,49 \mathrm{E}-02$ & $4,33 \mathrm{E}-02$ & $1,23 \mathrm{E}-04$ \\
\hline VALE3 & $5,50 \mathrm{E}-04$ & $5,59 \mathrm{E}-05$ & $5,09 \mathrm{E}-05$ & $9,92 \mathrm{E}-03$ & 4,33E-02 & 4,47E-02 \\
\hline VALE5 & $1,60 \mathrm{E}-04$ & $5,59 \mathrm{E}-05$ & 5,09E-05 & $2,33 \mathrm{E}-02$ & $4,33 \mathrm{E}-02$ & 4,47E-02 \\
\hline VIVO4 & $7,04 \mathrm{E}-03$ & $2,32 \mathrm{E}-03$ & $1,68 \mathrm{E}-02$ & $8,28 \mathrm{E}-04$ & $2,94 \mathrm{E}-03$ & $2,59 \mathrm{E}-04$ \\
\hline
\end{tabular}

Table 3 and the joint probabilities derived from those by applying the two alternative combination approaches in Table 4.

It can be noticed the strong agreement between the results of the two composition approaches after trimming is applied. PETR4 is now selected to be bought by both composition approaches and BTOW3 is selected to be sold. The next to extreme options are also the same for the different approaches. Similar results were obtained applying the methodology to data of that portfolio on other days of the same month.

It may be added that the opening and closure prices of PETR 4 and BTOW3 in the next day were 27,27 and 27,55 for the first and of 33,71 and 32,85 for the second. Thus, the earnings due to buying the first and selling the second would be around $1,0 \%$ in the first case and of $2,5 \%$ in the second. 
Table 4. Joint Probabilities derived from truncated data.

\begin{tabular}{|c|c|c|c|c|c|c|c|c|}
\hline \multirow[t]{2}{*}{ Title } & \multicolumn{2}{|c|}{$\begin{array}{l}\text { Joint minimization } \\
\text { all }\end{array}$} & \multicolumn{2}{|c|}{$\begin{array}{l}\text { Joint minimization } \\
\text { one }\end{array}$} & \multicolumn{2}{|c|}{$\begin{array}{c}\text { Joint maximization } \\
\text { all }\end{array}$} & \multicolumn{2}{|c|}{$\begin{array}{c}\text { Joint maximization } \\
\text { one }\end{array}$} \\
\hline & Probability & rank & Probability & Rank & Probability & Rank & Probability & Rank \\
\hline PETR4 & $1,94 \mathrm{E}-13$ & 61 & $1,75 \mathrm{E}-04$ & 61 & $7,46 \mathrm{E}-05$ & 1 & 0,121283 & 1 \\
\hline BBAS3 & $3,87 \mathrm{E}-13$ & 60 & $2,26 \mathrm{E}-04$ & 60 & $5,08 \mathrm{E}-05$ & 2 & 0,10819 & 2 \\
\hline VALE5 & $4,54 \mathrm{E}-13$ & 59 & $2,67 \mathrm{E}-04$ & 58 & $4,52 \mathrm{E}-05$ & 3 & 0,107395 & 3 \\
\hline ITSA4 & 4,91E-13 & 58 & $2,59 \mathrm{E}-04$ & 59 & $4,38 \mathrm{E}-05$ & 4 & 0,104848 & 4 \\
\hline GGBR4 & $6,64 \mathrm{E}-13$ & 57 & $3,40 \mathrm{E}-04$ & 57 & $3,53 \mathrm{E}-05$ & 5 & 0,102753 & 5 \\
\hline VALE3 & $1,37 \mathrm{E}-12$ & 56 & $5,89 \mathrm{E}-04$ & 55 & $2,12 \mathrm{E}-05$ & 7 & 0,096074 & 6 \\
\hline ITUB4 & $1,56 \mathrm{E}-12$ & 55 & $6,57 \mathrm{E}-04$ & 54 & $1,92 \mathrm{E}-05$ & 8 & 0,095122 & 7 \\
\hline BBDC4 & $2,01 \mathrm{E}-12$ & 53 & $8,15 \mathrm{E}-04$ & 53 & $1,57 \mathrm{E}-05$ & 9 & 0,093494 & 8 \\
\hline LREN3 & $1,57 \mathrm{E}-12$ & 54 & $4,00 \mathrm{E}-04$ & 56 & $2,2 \mathrm{E}-05$ & 6 & 0,086364 & 9 \\
\hline SBSP3 & $1,48 \mathrm{E}-10$ & 46 & $5,21 \mathrm{E}-02$ & 27 & $6,86 \mathrm{E}-08$ & 21 & 0,08609 & 10 \\
\hline PETR3 & $1,61 \mathrm{E}-10$ & 45 & 4,64E-02 & 38 & $8,45 \mathrm{E}-08$ & 20 & 0,081586 & 11 \\
\hline CIEL3 & $4,70 \mathrm{E}-11$ & 48 & $1,24 \mathrm{E}-02$ & 45 & $6,73 \mathrm{E}-07$ & 16 & 0,080515 & 12 \\
\hline TNLP4 & $2,81 \mathrm{E}-11$ & 51 & $6,05 \mathrm{E}-03$ & 47 & $1,53 \mathrm{E}-06$ & 13 & 0,076414 & 13 \\
\hline GOAU4 & $2,36 \mathrm{E}-10$ & 41 & 4,98E-02 & 33 & $5,96 \mathrm{E}-08$ & 23 & 0,075493 & 14 \\
\hline TRPL4 & $2,06 \mathrm{E}-10$ & 43 & $4,13 \mathrm{E}-02$ & 39 & $8,57 \mathrm{E}-08$ & 19 & 0,074636 & 15 \\
\hline GFSA3 & $2,73 \mathrm{E}-10$ & 40 & $4,65 \mathrm{E}-02$ & 37 & $6,33 \mathrm{E}-08$ & 22 & 0,070582 & 16 \\
\hline TLPP4 & $7,68 \mathrm{E}-12$ & 52 & $8,57 \mathrm{E}-04$ & 52 & $7,59 \mathrm{E}-06$ & 10 & 0,067742 & 17 \\
\hline USIM5 & $3,29 \mathrm{E}-10$ & 39 & $4,65 \mathrm{E}-02$ & 36 & $5,67 \mathrm{E}-08$ & 24 & 0,067445 & 18 \\
\hline BVMF3 & $2,16 \mathrm{E}-10$ & 42 & $2,70 \mathrm{E}-02$ & 41 & $1,33 \mathrm{E}-07$ & 18 & 0,067243 & 19 \\
\hline MRVE3 & $5,14 \mathrm{E}-10$ & 37 & $5,22 \mathrm{E}-02$ & 26 & $3,34 \mathrm{E}-08$ & 26 & 0,064129 & 20 \\
\hline CMIG4 & $4,24 \mathrm{E}-11$ & 50 & $3,55 \mathrm{E}-03$ & 48 & 1,61E-06 & 12 & 0,063067 & 21 \\
\hline CPFE3 & $7,58 \mathrm{E}-10$ & 36 & 4,67E-02 & 35 & $3,22 \mathrm{E}-08$ & 27 & 0,058795 & 22 \\
\hline PDGR3 & $8,37 \mathrm{E}-10$ & 35 & $5,00 \mathrm{E}-02$ & 31 & $2,68 \mathrm{E}-08$ & 28 & 0,058005 & 23 \\
\hline CSNA3 & $8,76 \mathrm{E}-11$ & 47 & $2,60 \mathrm{E}-03$ & 50 & $1,1 \mathrm{E}-06$ & 14 & 0,052986 & 24 \\
\hline ELET3 & $1,85 \mathrm{E}-09$ & 32 & $5,02 \mathrm{E}-02$ & 30 & $1,58 \mathrm{E}-08$ & 30 & 0,048383 & 25 \\
\hline LIGT3 & $3,43 \mathrm{E}-10$ & 38 & $8,95 \mathrm{E}-03$ & 46 & $2,53 \mathrm{E}-07$ & 17 & 0,048036 & 26 \\
\hline ELPL4 & 1,12E-09 & 34 & 2,91E-02 & 40 & 4,32E-08 & 25 & 0,047801 & 27 \\
\hline CYRE3 & $1,22 \mathrm{E}-09$ & 33 & 4,99E-02 & 32 & $2,27 \mathrm{E}-08$ & 29 & 0,047491 & 28 \\
\hline RDCD3 & $1,68 \mathrm{E}-10$ & 44 & $3,23 \mathrm{E}-03$ & 49 & $6,75 \mathrm{E}-07$ & 15 & 0,046644 & 29 \\
\hline UGPA4 & 1,71E-08 & 27 & $4,85 \mathrm{E}-02$ & 34 & $1,84 \mathrm{E}-09$ & 36 & 0,045462 & 30 \\
\hline CESP6 & 9,39E-09 & 28 & $5,51 \mathrm{E}-02$ & 21 & $3,12 \mathrm{E}-09$ & 34 & 0,04525 & 31 \\
\hline NATU3 & $3,38 \mathrm{E}-08$ & 26 & $6,42 \mathrm{E}-02$ & 19 & $6,38 \mathrm{E}-10$ & 41 & 0,045142 & 32 \\
\hline JBSS3 & $5,10 \mathrm{E}-08$ & 22 & 7,03E-02 & 16 & $3,5 \mathrm{E}-10$ & 44 & 0,044968 & 33 \\
\hline KLBN4 & $1,23 \mathrm{E}-07$ & 17 & $9,60 \mathrm{E}-02$ & 7 & $7,78 \mathrm{E}-11$ & 48 & 0,044804 & 34 \\
\hline CPLE6 & $4,60 \mathrm{E}-11$ & 49 & 1,31E-03 & 51 & $2,38 \mathrm{E}-06$ & 11 & 0,043434 & 35 \\
\hline
\end{tabular}


Table 4. Continued...

\begin{tabular}{|c|c|c|c|c|c|c|c|c|}
\hline \multirow[t]{2}{*}{ Title } & \multicolumn{2}{|c|}{$\begin{array}{l}\text { Joint minimization } \\
\text { all }\end{array}$} & \multicolumn{2}{|c|}{$\begin{array}{l}\text { Joint minimization } \\
\text { one }\end{array}$} & \multicolumn{2}{|c|}{$\begin{array}{l}\text { Joint maximization } \\
\text { all }\end{array}$} & \multicolumn{2}{|c|}{$\begin{array}{c}\text { Joint maximization } \\
\text { one }\end{array}$} \\
\hline & Probability & rank & Probability & Rank & Probability & Rank & Probability & Rank \\
\hline AMBV4 & $1,05 \mathrm{E}-07$ & 20 & $8,56 \mathrm{E}-02$ & 12 & $1,14 \mathrm{E}-10$ & 47 & 0,043371 & 36 \\
\hline RSID3 & $4,66 \mathrm{E}-09$ & 30 & $5,10 \mathrm{E}-02$ & 28 & 7,43E-09 & 33 & 0,04318 & 37 \\
\hline PCAR5 & $2,12 \mathrm{E}-09$ & 31 & $5,24 \mathrm{E}-02$ & 25 & $1,45 \mathrm{E}-08$ & 31 & 0,040038 & 38 \\
\hline ELET6 & $1,09 \mathrm{E}-07$ & 19 & $8,04 \mathrm{E}-02$ & 14 & $1,48 \mathrm{E}-10$ & 45 & 0,038672 & 39 \\
\hline BRTO4 & $1,57 \mathrm{E}-07$ & 13 & $9,37 \mathrm{E}-02$ & 9 & $7,62 \mathrm{E}-11$ & 49 & 0,038628 & 40 \\
\hline TAMM4 & $1,57 \mathrm{E}-07$ & 14 & 9,37E-02 & 10 & $7,62 \mathrm{E}-11$ & 50 & 0,038628 & 41 \\
\hline TMAR5 & $1,57 \mathrm{E}-07$ & 15 & $9,37 \mathrm{E}-02$ & 11 & $7,62 \mathrm{E}-11$ & 51 & 0,038628 & 42 \\
\hline BRFS3 & 4,71E-09 & 29 & $5,28 \mathrm{E}-02$ & 23 & 7,88E-09 & 32 & 0,034664 & 43 \\
\hline EMBR3 & $3,70 \mathrm{E}-08$ & 25 & $5,79 \mathrm{E}-02$ & 20 & $8,82 \mathrm{E}-10$ & 40 & 0,034649 & 44 \\
\hline BISA3 & $4,18 \mathrm{E}-08$ & 24 & $5,46 \mathrm{E}-02$ & 22 & $9,67 \mathrm{E}-10$ & 39 & 0,03082 & 45 \\
\hline DTEX3 & 4,91E-08 & 23 & $5,10 \mathrm{E}-02$ & 29 & 1,23E-09 & 38 & 0,019857 & 46 \\
\hline FIBR3 & $2,88 \mathrm{E}-07$ & 11 & $7,06 \mathrm{E}-02$ & 15 & $1,24 \mathrm{E}-10$ & 46 & 0,01608 & 47 \\
\hline TNLP3 & $1,35 \mathrm{E}-07$ & 16 & $5,27 \mathrm{E}-02$ & 24 & $5,32 \mathrm{E}-10$ & 43 & 0,012251 & 48 \\
\hline USIM3 & $1,14 \mathrm{E}-06$ & 10 & $9,41 \mathrm{E}-02$ & 8 & $2,12 \mathrm{E}-11$ & 52 & 0,010821 & 49 \\
\hline GOLL4 & $7,17 \mathrm{E}-08$ & 21 & $2,57 \mathrm{E}-02$ & 43 & 2,31E-09 & 35 & 0,007645 & 50 \\
\hline CSAN3 & $1,17 \mathrm{E}-07$ & 18 & 2,53E-02 & 44 & 1,36E-09 & 37 & 0,007526 & 51 \\
\hline CCRO3 & 2,04E-06 & 9 & $9,67 \mathrm{E}-02$ & 6 & $1,22 \mathrm{E}-11$ & 54 & 0,007117 & 52 \\
\hline ALLL3 & $3,56 \mathrm{E}-06$ & 7 & $1,00 \mathrm{E}-01$ & 5 & $6,84 \mathrm{E}-12$ & 56 & 0,00486 & 53 \\
\hline VIVO4 & 2,74E-07 & 12 & 2,59E-02 & 42 & $6,33 \mathrm{E}-10$ & 42 & 0,004028 & 54 \\
\hline SANB11 & $2,88 \mathrm{E}-06$ & 8 & $6,82 \mathrm{E}-02$ & 18 & $2,11 \mathrm{E}-11$ & 53 & 0,001917 & 55 \\
\hline CRUZ3 & $4,93 \mathrm{E}-06$ & 6 & $6,96 \mathrm{E}-02$ & 17 & $1,1 \mathrm{E}-11$ & 55 & 0,001468 & 56 \\
\hline TCSL4 & $1,84 \mathrm{E}-05$ & 4 & $1,05 \mathrm{E}-01$ & 4 & $1,23 \mathrm{E}-12$ & 58 & 0,000938 & 57 \\
\hline LAME4 & $1,27 \mathrm{E}-05$ & 5 & $8,32 \mathrm{E}-02$ & 13 & $2,97 \mathrm{E}-12$ & 57 & 0,000682 & 58 \\
\hline MRFG3 & $6,29 \mathrm{E}-05$ & 3 & $1,15 \mathrm{E}-01$ & 3 & $2,39 \mathrm{E}-13$ & 59 & 0,000189 & 59 \\
\hline BTOW3 & $1,20 \mathrm{E}-04$ & 1 & $1,41 \mathrm{E}-01$ & 1 & $7,01 \mathrm{E}-14$ & 60 & 0,000125 & 60 \\
\hline TCSL3 & $1,20 \mathrm{E}-04$ & 2 & $1,41 \mathrm{E}-01$ & 2 & $7,01 \mathrm{E}-14$ & 61 & 0,000125 & 61 \\
\hline
\end{tabular}

\section{Conclusion}

The case here studied shows how to apply probabilistic composition in a fast decision context. It serves to demonstrate the advantage of taking into account probabilistically the numerical distances between the evaluation values. The comparison in terms of joint probabilities of preference, by basing the scores on statistical distributions, takes all such distances into account.

An advantage of basing the decision on comparing the results of different points of view to the computation of joint probabilities of being ranked first is that the divergence between the results of these computations may be tracked to correct some vectors of initial evaluations. In the context of operational decisions, this may help to 
center attention on the criteria generating such particular vectors of evaluations, in a revising process and in an eventual change of the preferred composition point view. In the case here studied this allowed for producing corrections by trimming extreme values.

A final comment is called by the conceptual similarity between the probability of maximizing joint preferences by the probabilistic composition and the distance to the joint frontier in Data Envelopment Analysis - DEA (Charnes et al., 1978). The probability of reaching the frontier plays in the probabilistic composition a role similar to the distance to the frontier in DEA. Since DEA distances are calculated to a frontier formed by observed values, a comparison to the scores resulting from DEA with constant inputs models might be useful. In practice, DEA efficiency scores include a large number of fully efficient tied options, especially in the case of a large set of evaluators. The same happened in the application here discussed after the extreme observed values were truncated. It must be noticed that this did not embarrass the fast evaluation process, as the evaluations according to the different criteria presented their extreme values at different options.

\section{Acknowledgements}

The authors would like to thanks the journal anonymous reviewers for their contribution. This paper is part of a research study funded by the Brazilian Research Council (CNPq) and Coordination for the Qualification of Higher Education Personnel (CAPES).

\section{References}

Arrow, K.J. (1951) Social Choice and Individual Values. New York: J. Wiley.

Bronner, R. (1982) Decision making under time pressure. Lexington: D. C. Heath.

Charnes, A.; Cooper, W.W. and Rhodes, E. (1978) Measuring the efficiency of decision-making units. European Journal of Operational Research, Vol. 2, pp. 429-444. http:// dx.doi.org/10.1016/0377-2217(78)90138-8

Charnetski, J.R. and Soland, R.M. (1978) Multiple-attribute decision making with partial information: the comparative hypervolume criterion. Naval Research Logistics Quarterly, Vol. 25, pp. 279-288. http://dx.doi.org/10.1002/nav.3800250208

Cohen, M.; Freeman, J. and Wolf, S. (1996) Metarecognition in time-stressed decision making: recognizing, critiquing and correcting. Human Factors, Vol. 38, No. 2, pp. 206-219. http://dx.doi.org/10.1518/001872096779048020

Eisenhardt, K (1989) Making fast strategic decisions in high-velocity environments. Academy of Management Journal, Vol. 32, No. 3, pp. 543-576. http://dx.doi.org/10.2307/256434

Fisher, C.; InduShobha, C. and Ballou, D. (2003) The Impact of Experience and Time on the Use of Data Quality Information in Decision Making. Information Systems Research, Vol. 14, No. 2, pp. 170-188. http://dx.doi.org/10.1287/isre.14.2.170.16017

Lahdelma, R.; Hokkanen, J. and Salminen, P. (1998) SMAA - Stochastic multiobjective acceptability analysis. European Journal of Operational Research, Vol. 106, No. 1, pp. 137-143. http://dx.doi.org/10.1016/S0377-2217(97)00163-X

Larson, A. (2010) The Impact of Computer Decision Support on Military Team Decision Making. Dissertation. University of Minnesota, Minneapolis, USA.

Laxmisan, A.; Hakimzada, F.; Sayan, O.; Green, R.; Zhang, J. and Patel, V. (2007) The multitasking clinician: decision-making and cognitive demand during and after team handoffs in emergency care. International Journal of Medical Informatics, Vol. 76, pp.801-811. PMid:17059892. http://dx.doi.org/10.1016/j.ijmedinf.2006.09.019 
Lehner, P.; Seyed-Solorforough, M.; O’Connor, M.; Sak, S. and Mullin, T. (1997) Cognitive biases and time stress in team decision making. IEEE Transactions on Systems, Man, and Cybernetics, Vol. 27, No. 5, pp. 698-703. http://dx.doi.org/10.1109/3468.618269

Likert, R. (1932) A Technique for the Measurement of Attitudes. Archives of Psychology, Vol.140, pp. 1-55.

Louvieris, P.; Gregoriades, A. and Garn, W. (2010) Assessing critical success factors for military decision support. Expert Systems with Applications, Vol. 37, No. 12, pp. 8229-8241. http://dx.doi.org/10.1016/j.eswa.2010.05.062

Sant'Anna, A.P. (2002) Data Envelopment Analysis of Randomized Ranks. Pesquisa Operacional, Vol. 22, No. 2, pp. 203-215. http://dx.doi.org/10.1590/S0101-74382002000200007

Walk, S. (2011) A new fast reliable filtering method for multicrfiteria decision making. Management Decision, Vol. 49, No. 5, pp. 810-822. http://dx.doi.org/10.1108/00251741111130878

Zadeh, L.A. (1965) Fuzzy sets. Information and Control, Vol. 8, pp. 338-353. http:// dx.doi.org/10.1016/S0019-9958(65)90241-X

Zadeh, L.A. (1978) Fuzzy Sets as the Basis for a Theory of Possibility. Fuzzy Sets and Systems, Vol. 1, pp. 3-28. http://dx.doi.org/10.1016/0165-0114(78)90029-5

\section{Biography}

Annibal Parracho Sant'Anna is a Professor at Universidade Federal Fluminense. Ph.D. in Statistics by the University of California, Berkeley, M. Sc in Mathematics by IMPA/CNPq, he graduated in Mathematics and in Economics at Universidade Federal do Ro de Janeiro. He developed Pos-doctoral studies at the University of New South Wales. He has been the Head of the Institute of Mathematics and of the Laboratory of Statistics of Universidade Federal do Rio de Janeiro. He was until recently the President of the Brazilian Society of Operations Research.

Contact: tppaps@vm.uff.br

Helio Darwich Nogueira is a doctorate student in Production Engineering at Universidade Federal Fluminense, Rio de Janeiro. He is specialised in Finance by COPPEAD at Universidade Federal do Rio de Janeiro and in Management by Universidade Cândido Mendes, Rio de Janeiro. He has many years of experience in Finance working as a consultant and is a director at the Capital Markets Investments Professionals and Analysts Association - APIMEC.

Contact: hdarwich@uol.com.br

Lúcia Mathias Rabelo is a doctorate student in Production Engineering at Universidade Federal Fluminense, Rio de Janeiro. She has Master 's Degrees in Production Engineering and in International Management. She teaches at Univercidade, Rio de Janeiro at the Engineering Production Department. Her research interests are in decision support systems, strategic management and business processes management.

Contact: lurabelo2009@gmail.com

\section{Article Info:}

Received: April, 2011

Accepted: July, 2011 